\title{
The hydrometeorological conditions of phytoplankton growth in the water reservoirs of the Moscow Canal
}

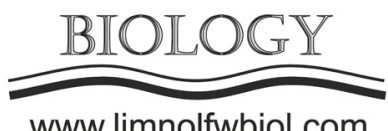

www.limnolfwbiol.com

\author{
Goncharov A.V. ${ }^{1 *}$, Puklakov V.V. ${ }^{1}$, Alekseeva L.I. ${ }^{1}$, Zamana V.G. ${ }^{2}$ \\ ${ }^{1}$ Lomonosov Moscow State University, Faculty of Geography, Moscow, 119991 Russia, \\ ${ }^{2}$ JSC Mosvodokanal, Pleteshkovsky pereulok, 2, Moscow, 105005 Russia
}

\begin{abstract}
Based on the results of perennial observations (1964-2011), it is shown that the degree of phytoplankton growth in the water reservoirs of the Moscow Canal (Ikshinskoye, Pestovskoye, Uchinskoye, Pyalovskoye, and Klazminskoye reservoirs) is directly dependent on the amount of the inflow of water bringing nutrient elements from the territory of the catchment. This factor influences both seasonal and perennial variations in the amount of phytoplankton biomass. The influence of meteorological factors on the runoff in this region is demonstrated. The strong impact of the hydrometeorological factors on the phytoplankton is explained by the polymictic nature of the water reservoirs in question, as well as by the scarcity of the nutrient elements in the Upper Volga waters.
\end{abstract}

Keywords: phytoplankton, water reservoir, phosphorus, runoff, climate change

The water reservoirs under study - Ikshinskoye, Pestovskoye, Uchinskoye, Pyalovskoye, and Klazminskoye - are lined along the Moscow Canal, which carries the water of the Volga River from Ivankovskoye reservoir to the city of Moscow. The water system was established in 1937 and is one of the main sources of water supply for Moscow.

The biological productivity of the said water reservoirs is not high. At the same time, they differ among each other by the degree of phytoplankton growth; there are also essential differences by seasons and years. This study is devoted to clarification of the causes of the spatial and temporal changes of phytoplankton in the water reservoirs of the Moscow Canal (MC).

The study is based on analysis of the materials of perennial observations made by JSC Mosvodokanal over the composition and quality of water in the MC water reservoirs in 1961-2012. Data were also used provided by the JSC Moscow Canal on the water balance of the water reservoirs, as well as data of Rosgidromet on the levels and water discharge in the Volga River near the town of Staritsa, and the results of publications and our own observations.

Comparison of the mean perennial values of the amount of phytoplankton biomass in the vegetation period shows that the largest phytoplankton growth was observed in Klazminskoye (3.1 mg/l), Pyalovskoye $(2.6 \mathrm{mg} / \mathrm{l})$ и Pestovskoye $(2.3 \mathrm{mg} / \mathrm{l})$ reservoirs, while the lowest value was found in Uchinskoye $(1.4 \mathrm{mg} / \mathrm{l})$ and Ikshinskoye $(1.0 \mathrm{мг/л)} \mathrm{reservoirs.} \mathrm{What} \mathrm{were} \mathrm{the}$ differences related to?
Examining different reservoir parameters, we noticed that one of them, specific catchment (the relation of the catchment area to the reservoir area), closely correlates with the amount of phytoplankton biomass discussed above $(r=0.88)$. This fact testifies that, the greater the specific catchment value is, the greater is the water runoff (per area unit of the water reservoir), together with the supply of nutrient elements which trigger the phytoplankton growth. Indeed, the use of data on the concentration of phosphorus (phosphates) showed a significant relation $(r=0.91)$ between them and the specific water catchment, as expected. At that, we operated with the phosphate concentration in April, when those substances were not yet consumed by the phytoplankton biomass. There is also a relation between the phytoplankton biomass and the phosphate concentration $(r=0.71)$.

In the seasonal fluctuations of the phytoplankton growth in the reservoirs in question, the main spring peak of the phytoplankton biomass is evident. In more productive reservoirs (Klazminskoye, Pyalovskoye), its value is greater; an autumn rise of the biomass is observed, too. Such facts have been described in literature (Trifonova, 1990): in low-productivity water bodies (lakes) of the temperate zone only one main spring maximum of the phytoplankton growth is observed, caused by enrichment of the euphotic zone by nutrient elements during convective mixing of the water mass in spring. The second less expressed peak of the phytoplankton biomass growth is possible during autumn convection.

At the same time, the reservoirs considered

*Corresponding author.

E-mail address: mama15333@mail.ru (A.V. Goncharov)

(C) Author(s) 2020. This work is distributed under the Creative Commons Attribution 4.0 License. 
are characterized by a very high water renewal rate (from 7.4 to $181 \mathrm{yr}^{-1}$ ), their water mass is sufficiently homogeneous; therefore, convective mixing should not essentially change the concentration of nutrient elements in them. The spring maximum phytoplankton biomass may be caused not by mixing of the water mass but by the inflow of a large amount of water enriched with nutrient elements washed out from the soils of the watersheds. It is shown in the study by Yu.S. Datsenko and M.B. Zaslavskaya (Datsenko and Zaslavskaya, 2012) that the largest amount of phosphorus comes to the reservoirs in question from outside in spring, at the time of the spring flood.

Analysis of the perennial changes (1964-2011) made for the best studied Uchinskoye reservoir showed that the largest amount of the phytoplankton biomass was recorded in the 1980 s. It was approximately 2-3 times greater than in the preceding or subsequent periods. It is noteworthy that the maximum lateral inflow of water in the reservoirs (according to JSC Moscow Canal) also occurred at that time, just as the rise in the concentration of phosphates. That means, a significant role of the river runoff bringing nutrient elements is manifested in the perennial variations of the amount of the phytoplankton biomass.

It is evident that the perennial variations in the river runoff occur in large territories, not only in the local catchments of the reservoirs under study. Therefore, we can expect a similar character in the river runoff of the entire Upper Volga, from where water comes to the MC reservoirs. The diagram of the perennial (19612011) water discharge in the Volga River near the town of Staritsa confirmed this supposition; in addition, for the 1980 s increased concentration of phosphates in the water coming to the Moscow Canal from the Volga River (from Ivankovskoye reservoir) was revealed.

It is likely that the river runoff largely depends on the amount of the precipitation fall. This is well confirmed by comparison of the diagrams of the water discharge of the Volga River we developed and of the perennial variations in the precipitations recorded at the nearby meteorological station of the town of Klin. In it turn, precipitation depends on the cyclonic activity which is determined by quasi-rhythmical fluctuations of different time scales, such as the North Atlantic Oscillation, NAO. As the NAO index rises, in Northern and North-Eastern Europe the amount of precipitation increases, which was especially evident in 1981 - 1995 (Kislov et al., 2008).

Thus, the study conducted revealed an interesting fact: the spatial and temporal distribution of phytoplankton in the MC reservoirs is largely determined by one principal factor, the water runoff, which, in its turn, depends on the meteorological conditions, including climate changes. In our opinion, this is caused, firstly, by the polymictic nature of the said reservoirs, and, secondly, by the general scarcity of nutrient elements in the waters of the Upper Volga River, therefore, a small rise of their inflow into the reservoirs in the periods of increased runoff increases the biological productivity of the water reservoirs.

\section{References}

Datsenko Y.S., Zaslavskaya M.B. 2012. Balance evaluation of the role of lateral inflow in water quality formation in the reservoirs of the water divide reach of the Moscow Canal. Vodnyye Resursy [Water Resources] 39: 98-104. (in Russian)

Kislov A.V., Evstigneyev V.M., Malkhazova S.M. et al. 2008. Prognoz klimaticheskoy resursoobespechennosti Vostochno-yevropeyskoy ravniny $\mathrm{v}$ usloviyakh potepleniya XXI veka [Estimate of climatic resource sustenance of the Russian plain under conditions of climate warming of the 21st century]. Moscow: MAX Press. (in Russian)

Trifonova I.S. 1990. Ekologiya i suktsessiya ozernogo fitoplanktona [The ecology and succession of lake phytoplankton]. Leningrad: Nauka. (in Russian) 